\title{
Protective Efficacy of Novel Oral Biofilm Vaccines against Lactococcus garvieae Infection in Mullet, Mugil cephalus
}

\author{
Feng-Jie Su and Meei-Mei Chen *
}

check for updates

Citation: Su, F.-J.; Chen, M.-M. Protective Efficacy of Novel Oral Biofilm Vaccines against Lactococcus garvieae Infection in Mullet, Mugil cephalus. Vaccines 2021, 9, 844 https://doi.org/10.3390/ vaccines 9080844

Academic Editor: Takashi Imai

Received: 14 June 2021

Accepted: 29 July 2021

Published: 1 August 2021

Publisher's Note: MDPI stays neutral with regard to jurisdictional claims in published maps and institutional affiliations.

Copyright: (c) 2021 by the authors. Licensee MDPI, Basel, Switzerland. This article is an open access article distributed under the terms and conditions of the Creative Commons Attribution (CC BY) license (https:// creativecommons.org/licenses/by/ $4.0 /)$.
Department of Veterinary Medicine, National Taiwan University, No. 1, Section 4, Roosevelt Road, Taipei 10617, Taiwan; d06629003@ntu.edu.tw

* Correspondence: cmm@ntu.edu.tw; Tel.: +886-2-3366-3875

\begin{abstract}
Lactococcus garvieae (L. garvieae) is an important pathogen that causes enormous economic losses in both marine and freshwater aquaculture. At present, antibiotics are the only option for farmers to reduce the losses caused by L. garvieae. However, the usage of antibiotics leads to environmental pollution and the production of drug-resistant strains of bacteria. Therefore, vaccination is preferred as an alternative method to prevent infectious diseases. In this study, we describe an effective approach to the production of an oral biofilm vaccine, using bacteria grown on chitosan particles to form biofilms, and thus providing an inactive pathogen that enhances the immune response in fish. We observed the formation of a biofilm on chitosan particles and administered the novel oral biofilm vaccine to fish. We analyzed the immune responses, including antibody production, phagocytic ability, albumin/globulin ratio and immune-related genes, of vaccinated and control groups of black mullet. Our results show that the phagocytic ability of the biofilm vaccine group was $84 \%$, which is significantly higher than that of the control group, and the antibody production in this group was significantly higher compared with the other group. The mRNA expression levels of immune-related genes (TLR2, IL-1 $\beta$, TNF- $\alpha$ ) were significantly upregulated in the spleen after vaccination. In challenge experiments, the relative percent survival (RPS) was $77 \%$ in the biofilm vaccine group, $18 \%$ in the whole-cell vaccine group, and $0 \%$ in the chitosan particle group at 32 days post-vaccination. In addition, we also found that the relative percent survival (RPS) at 1 day post-vaccination was $74 \%$ in the biofilm vaccine group, $42 \%$ in the whole-cell vaccine group, and $26 \%$ in the chitosan particle group. In both long-term and short-term challenge experiments, the viability of the biofilm vaccine group was significantly higher than that of the whole-cell, chitosan particle and PBS groups. We conclude that based on its protective effect, the L. garvieae biofilm vaccine is better than the whole-cell vaccine when challenged several weeks after vaccination. In addition, the biofilm vaccine also has a greater protective effect than the whole-cell vaccine when challenged immediately after vaccination. Therefore, the biofilm vaccine might represent a novel method for the prevention and treatment of L. garvieae infection.
\end{abstract}

Keywords: oral biofilm vaccine; Lactococcus garvieae; Mugil cephalus; IgM

\section{Introduction}

Lactococcus garvieae is a facultative anaerobic, non-motile and Gram-positive bacteria that infects many fish species and causes enormous economic losses in both marine and freshwater aquacultures [1]. In tilapia and grey mullet aquaculture, infection with L. garvieae leads to $70-100 \%$ morbidity rates, with clinical symptoms of exophthalmia, ascites haemorrhage and septicaemia [2,3]. In addition, surviving fish may suffer from chronic or persistent infections. It has been reported that biofilm formation is an important mechanism of chronic infection. Approximately $80 \%$ of persistent bacterial infections may be related to biofilm formation [4]. Biofilms are formed by bacteria, enabling them to resist environmental stresses such as oxidative stress, $\mathrm{pH}$ change, antibacterial substances, and the host immune system [5]. The composition of the biofilm matrix enables bacteria to 
deceive the host immune system and escape the immune response. For instance, after Streptococcus pneumonia infection, the bacteria trigger an acute response, as bacteraemia stimulates the immune system of the host and induces humoral immunity against planktonic bacterial antigens. Then, the bacteria form biofilms in the brain, spleen, kidneys and other tissues to escape the immune response. A bacterial biofilm consists of bacteria embedded in a complex array of extracellular substances, including extracellular DNA, peptidoglycans, extracellular proteins and a capsular layer [6]. Therefore, the biofilm antigenicity and immunogenicity are considerably different from those of the planktonic bacteria, and the biofilm elicits a different immune response in the host [7]. In previous studies, the different antigenicity and immunogenicity qualities of biofilms were identified and used to search for new antigens to improve existing vaccines or to develop new ones [8]. For instance, immunisation with polysaccharides from the biofilm matrix of S. aureus induced protective immunity against infections of the mammary gland of sheep and cows and prevented biofilm formation [9]. In a mouse model study, a biofilm LytB protein vaccine was immunogenic, and enhanced complement-mediated immunity and the phagocytosis of different serotypes of S. pneumoniae [10].

The development of a vaccine for oral administration involves confirming that the antigen is efficiently delivered to gut-associated lymphoid tissues (GALTs). GALTs are important immune tissues that play a crucial role in the gut to prevent infection [11]. Biofilms with multiple immunogenicity can protect bacteria from destruction by gastric acid. The biofilm vaccine model was further strengthened by the demonstration of the localisation and distribution of antigen in larger quantities for a longer duration in the gut and lymphoid tissues following oral vaccination in [12]. An oral biofilm vaccine was shown to induce specific IgM in vaccinated fish [13]. In addition, oral vaccines resulted in the upregulation of genes related to the recruitment of immune cells in [14]. These results suggest that biofilm is the best choice as the basis for the development of an oral vaccine.

Recent methods for developing oral biofilm vaccines mainly use chitin flakes, and have achieved good protective effects in a variety of fish species, such as common carp (Cyprinus carpio) [12,15], catfish (Clarias batrachus) [16], rohu (Labeo rohita) [17], red hybrid tilapia (Oreochromis sp.) [18] and Asian seabass (Lates calcarifer) [19]. In addition, oral vaccines use chitosan polymer-based, coated and inactivated bacteria to enhance protective efficacy $[20,21]$.

In this study, we developed a new method for preparing an oral biofilm vaccine. We grew bacteria in suspension culture on chitosan particles to form a biofilm, and then the biofilm formation was monitored at different time points. Subsequently, we investigated the potential of the biofilm vaccine against Lactococcus garvieae by incorporating it into feed. We used immunohistochemistry (IHC) to monitor the delivery of oral vaccines. The antibody responses in the serum, the phagocytic ability, the albumin/globulin ratio and immune-related genes (C3, TLR2, IL-1 $\beta$, and TNF- $\alpha$ ) were analysed, and a challenge test was performed to confirm the protective efficacy of the oral vaccine.

\section{Materials and Methods}

\subsection{Ethical Considerations}

The present animal experimental study was approved by the Centre for Research Animal Care and observed by the Animal Care Use Committee of the National Taiwan University (protocol no. B201800003).

\subsection{Experimental Fish}

Black mullets were purchased from a mullet farm in Hsinchu, Taiwan. Two hundred and twenty-four black mullets that were maintained in an $800 \mathrm{~L}$ fibre-reinforced plastic (FRP) tank in brackish water $(20 \mathrm{ppt})$ at $25^{\circ} \mathrm{C}$. For laboratory trials, fish $(5 \mathrm{~g} \pm 0.3 \mathrm{~g})$ were reared in an indoor recirculated aquatic animal culture system at a regulated temperature of $26 \pm 2.0^{\circ} \mathrm{C}$ at the Department of Veterinary Medicine, National Taiwan University (Taipei, Taiwan). Tanks were provided with UV-treated and filtered water throughout this 
period, and $50 \%$ of the water was changed twice weekly. Spleens of 5 randomly selected fish were collected for bacterial isolation and polymerase chain reaction (PCR) analysis to confirm they were free from L. garvieae before conducting the experiments [22].

\subsubsection{Chitosan Particles}

The method for preparing chitosan particles was modified from a previous study [23]. The chitosan particles were prepared by dissolving $1 \mathrm{~g}$ of chitosan powder (Sigma-Aldrich, Taiwan) in $1000 \mathrm{~mL}$ of $\mathrm{ddH}_{2} \mathrm{O}$ with $2 \%$ acetic acid, and then $\mathrm{pH}$ was adjusted to 7.0 with $1 \mathrm{~N} \mathrm{NaOH}$ to form particles. The particles were stored at $4{ }^{\circ} \mathrm{C}$.

\subsubsection{Bacterial Strains}

L. garvieae was isolated from outbreaks in moribund black mullets at Taiwan fish farms. L. garvieae was isolated on blood agar (Oxoid ${ }^{\mathrm{TW}}$, Creative Media Plate, Taiwan) and identified by sequencing $16 \mathrm{~S}$ rRNA genes [22]. A single colony was isolated and enriched in $3 \mathrm{~mL}$ of brain-heart infusion (BHI; HiMedia, Creative Media Plate, Taiwan) broth containing $1 \% \mathrm{NaCl}$ at $28^{\circ} \mathrm{C}$ overnight in an incubator shaker. Then, cells were harvested by centrifugation at 10,000 rpm for $10 \mathrm{~min}$. Subsequently, the pellet was resuspended in BHI with $18 \%$ glycerol as the stock suspension and stored at $-20{ }^{\circ} \mathrm{C}$.

\subsubsection{Cultured and Quantified L. garvieae Biofilm}

The biofilm was quantified by the DMMB method, and the data were converted to colony-forming units. L. garvieae was cultured at a density of $10^{4} \mathrm{CFU} / \mathrm{mL}$ in $100 \mathrm{~mL}$ of BHI with $1 \% \mathrm{NaCl}$ and $10 \mathrm{mg} / \mathrm{mL}$ chitosan particles and rotated at $100 \mathrm{rpm}$, and $1 \mathrm{~mL}$ samples were taken at $1,3,5,7,24,48$ and $72 \mathrm{~h}$. The samples were washed twice with $0.01 \mathrm{M}$ phosphate-buffered saline (PBS, pH 7.4) and harvested by centrifugation at $300 \mathrm{rpm}$ for $10 \mathrm{~min}$ to remove excess medium on the chitosan particles. Then, $1 \mathrm{~mL}$ of PBS was added to each Eppendorf tube, and the biofilm was homogenised to disassociate it from the chitosan particles. BHI agar plates were inoculated with the homogeneity biofilm and incubated at $28{ }^{\circ} \mathrm{C}$ for $24 \mathrm{~h}$. CFU $/ \mathrm{mL}$ values were then calculated. The biofilm was quantitated using the DMMB method [24]. L. garvieae biofilm samples were measured at $620 \mathrm{~nm}$ using a spectrophotometer (BioPhotometer, Eppendorf, Taiwan). Scanning electron microscopy (SEM) was used to ensure that the chitosan particles were encapsulated in the biofilm. The SEM samples were viewed with a JeoL JSM-7800F (JEOL Ltd., Tokyo, Japan) scanning electron microscope at $15 \mathrm{kV}$ using a $15-17 \mathrm{~mm}$ working distance, and photographs were taken.

\subsubsection{Preparation of L. garvieae Biofilm and Whole-Cell Vaccines}

L. garvieae bacteria were cultured in $100 \mathrm{~mL}$ of $\mathrm{BHI}$ broth containing $1 \% \mathrm{NaCl}$ and $10 \mathrm{mg} / \mathrm{mL}$ chitosan particles and rotated (100 rpm) at $28^{\circ} \mathrm{C}$ for $48 \mathrm{~h}$. Then, biofilms were harvested by centrifugation at $300 \mathrm{rpm}$ for $10 \mathrm{~min}$ at $4{ }^{\circ} \mathrm{C}$ and washed thrice with sterile PBS. In addition, we added $1 \mathrm{~mL}$ PBS with biofilm into Eppendorf tubes, and the biofilm was homogenised to disassociate it from the chitosan particles. BHI agar plates were inoculated with the homogeneity biofilm and incubated at $28{ }^{\circ} \mathrm{C}$ for $24 \mathrm{~h}$. CFU/mL values were then calculated. The final biofilm was inactivated with $2 \%(w / v)$ formalin for $24 \mathrm{~h}$. Inactivated biofilm was washed thrice with sterile PBS. The biofilm vaccine was stored at $4{ }^{\circ} \mathrm{C}$. For the preparation of the whole-cell vaccine, the described strain was inoculated in $\mathrm{BHI}$ containing $1 \% \mathrm{NaCl}$ and rotated at $100 \mathrm{rpm}$ at $28^{\circ} \mathrm{C}$ for $7 \mathrm{~h}$. The pellet was harvested by centrifugation at 10,000 rpm for $10 \mathrm{~min}$ and washed thrice using PBS. In addition, $1 \mathrm{~mL}$ PBS with whole cells was added into Eppendorf tubes and grown on BHI agar plates at $28^{\circ} \mathrm{C}$ for $24 \mathrm{~h}$; then, $\mathrm{CFU} / \mathrm{mL}$ values were calculated. The resulting cells were inactivated with $2 \%(w / v)$ formalin for $24 \mathrm{~h}$. Inactivated whole cells were washed thrice with sterile PBS. The whole-cell vaccine was stored at $4{ }^{\circ} \mathrm{C}$. 


\subsection{Preparation of Feed-Based Biofilm and Whole-Cell Vaccines}

The feed-based method was modified from a previous study [18]. The biofilm vaccine and whole-cell vaccine were each resuspended in PBS solution to a concentration of $10^{10} \mathrm{CFU} / \mathrm{mL}$ and mixed thoroughly before spraying onto a pellet mixture using a homogeniser (PowerMasher II, OPTIMA Ltd., Tokyo, Japan) to incorporate the vaccines into the commercial feed. Finally, the prepared feed was pelleted using a pelletiser machine and dried at $70{ }^{\circ} \mathrm{C}$ for $24 \mathrm{~h}$ in an oven before the experiment.

\subsection{Vaccination}

\subsubsection{Experimental Design 1}

The time course of vaccination and sampling are shown in Figure 1. After one month of acclimation in FRP tanks, the fish were divided into four groups and moved to $80 \mathrm{~L} F R P$ tanks, each containing 23 fish. Four groups were established: the biofilm vaccine group, whole-cell group, the chitosan particle group and the PBS group. Each were vaccinated for 14 consecutive days. The collected samples were analysed for immune-related genes. The collected blood was analysed to measure phagocytic ability, albumin-globulin ratio and antibodies after vaccination. The vaccinated fish in each group were challenged with L. garvieae at 1 day post-vaccination (Figure 1). Finally, the survival rate was calculated.

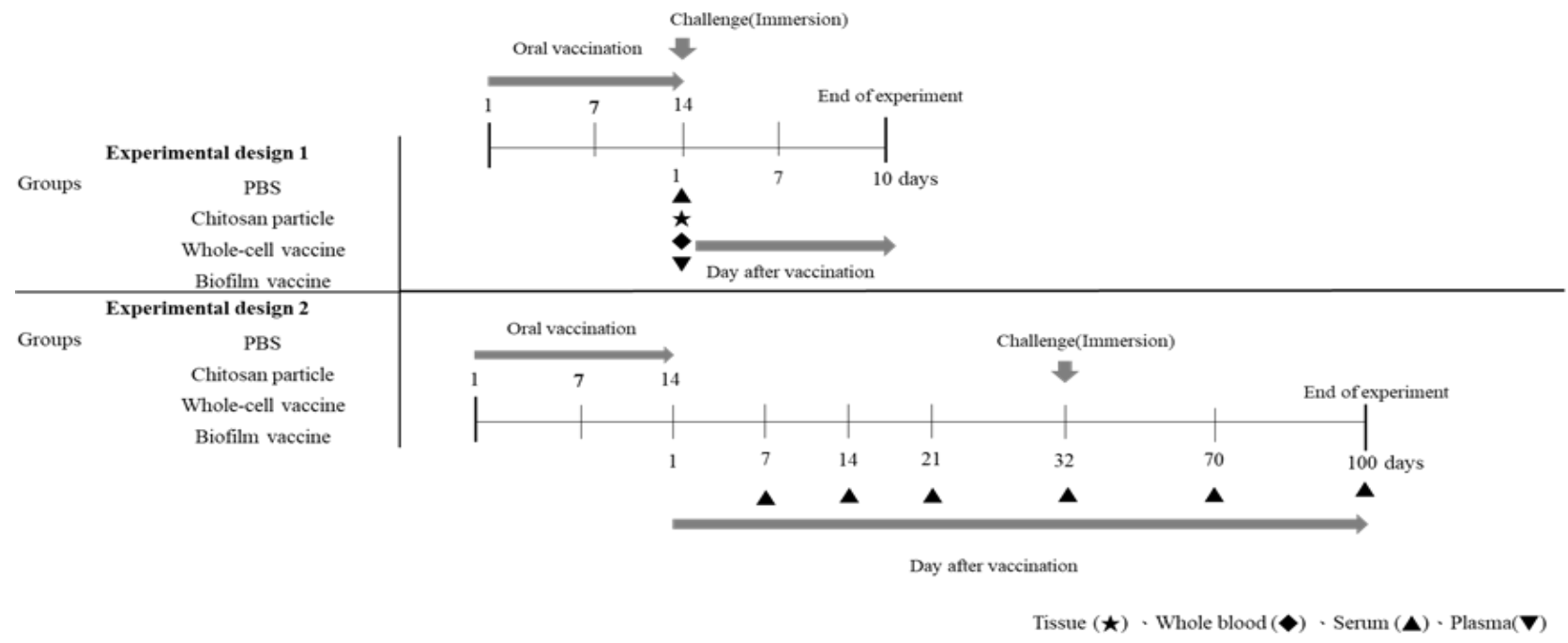

Figure 1. Graphical overview of the vaccination/challenge schedule and sampling time points.

\subsubsection{Experimental Design 2}

The time course of vaccination and sampling is shown in Figure 1. Experiment 2 was designed for the long-term evaluation of antibody titres and L. garvieae challenge tests. The fish were divided into four groups and moved to $80 \mathrm{~L}$ FRP tanks, each containing 33 fish. Four groups were established: the biofilm vaccine group, the whole-cell group, the chitosan particle group and the PBS group; each were vaccinated for 14 consecutive days. The blood was collected 7, 14, 21, 32, 70 and 100 days post-vaccination. Twenty-five fish in each group were randomly selected and challenged with $L$. garvieae at 32 days post-vaccination (Figure 1). Finally, the survival rate was calculated. The remaining 8 fish in each group were not challenged with the pathogen, and the antibody response was monitored on days 70 and 100 following the completion of the vaccination program.

\subsection{Immunohistochemistry}

The fish were euthanised by anaesthetic, and the abdominal cavity was cut to obtain the spleen, head kidney and intestine. The spleen, head kidney and intestine were fixed in $10 \%$ neutral buffered formalin for at least $24 \mathrm{~h}$, and blank tissue sections were prepared for immunohistochemical staining. Tissue sections were deparaffinised and then rehydrated 
following a standard procedure. The rehydrated slides were immersed in Trilogy ${ }^{\mathrm{TM}}$ (Cell Marque, Rocklin, CA, USA) at $121{ }^{\circ} \mathrm{C}$ for $15 \mathrm{~min}$ for antigen retrieval. The tissue sections were cooled down on the bench top for $30 \mathrm{~min}$. Then, the CRF Anti-Polyvalent HRP Polymer (DAB) stain kit (ScyTek, Taiwan) was applied according to the manufacturer's instructions. To detect biofilm antigens, tissue sections were incubated with primary antibody (polyclonal rabbit anti-L. garvieae biofilm antibody from our laboratory) at a dilution of 1:500 in $0.05 \mathrm{M}$ Tris buffer ( $\mathrm{pH} 7.6$ ) for $1 \mathrm{~h}$. The antibody was replaced with non-immune rabbit serum in negative controls.

\subsection{Phagocytic Ability and Albumin-Globulin Ratio Analyses}

After vaccination, 3 fish from each experimental group were taken randomly and sedated with $30 \mathrm{ppm}$ tricaine methanesulfonate (MS-222) in brackish water. Blood was drawn from the caudal vein using a $1 \mathrm{~mL}$ plastic syringe (27G) rinsed with $120 \mathrm{mM}$ EDTA. Clean brackish water was used to observe the state of the fish, which were returned to the experimental group after they recovered and resumed swimming. For the phagocytic assay, $10^{7}$ cells of formalin-killed L. garvieae were added to $50 \mu \mathrm{L}$ of pooled blood samples in a sterile microplate and incubated for $30 \mathrm{~min}$ at $25^{\circ} \mathrm{C}$ after thoroughly mixing in the well. Following incubation, the blood-bacteria suspension was pipetted, and $25 \mu \mathrm{L}$ of this suspension was smeared on 3 glass slides. After air drying, the smears were fixed in 95\% ethanol, redried and stained with May-Grunwald-Giemsa. The phagocytic cells with phagocytosed bacteria were counted [25]. The albumin-globulin ratios (A/G) in the sera were calculated by following the method of Thanga Viji et al. [26]. The plasma samples were analysed for total protein (following the dye-binding method of Bradford (1976) using bovine serum albumin as the standard), albumin (using the bromocresol green method (MeDiPro, Taiwan)) and globulin (by subtracting the albumin value from the total protein value). Finally, the A/G ratio was calculated.

\subsection{Antibody Detection}

Serum antibodies were collected using a method modified from a previous study [18]. Three fish from each experimental group were taken randomly and sedated with $30 \mathrm{ppm}$ tricaine methanesulfonate (MS-222) in brackish water. Blood was drawn from the caudal vein using a $1 \mathrm{~mL}$ plastic syringe (27G) without anticoagulant and stored at $4{ }^{\circ} \mathrm{C}$ overnight (to collect the serum), after which serum was extracted by centrifugation for $5 \mathrm{~min}$. Clean brackish water was used to observe the state of the fish, which were returned to the experimental group after they recovered and resumed swimming. Antibody titres against $L$. garvieae biofilm or whole-cell bacteria were assayed by ELISA. Briefly, a 96-well microplate was coated with $1 \times 10^{8} \mathrm{CFU} / \mathrm{mL}$ L. garvieae biofilm or whole-cell bacteria in $100 \mu \mathrm{L}$ of coating buffer (50 mM carbonate buffer, $\mathrm{pH} 9.6)$ at $4{ }^{\circ} \mathrm{C}$ overnight, then washed with PBS containing 0.05\% Tween-20 (PBST) and blocked in PBST containing 1\% BSA (PBSTB) at $28^{\circ} \mathrm{C}$ for $1 \mathrm{~h}$. After blocking, the wells were washed three times with $150 \mu \mathrm{L}$ of PBST, and mullet serum (100 $\mu \mathrm{L} /$ well $)$ in a 1:300 dilution in PBST was added to the wells. After incubation at $28^{\circ} \mathrm{C}$ for $1 \mathrm{~h}$, they were washed three times, and $100 \mu \mathrm{L}$ of mouse-antifish IgM HRP monoclonal antibody (Aquatic Diagnostics Ltd., Stirling, UK, 1:300 dilutions in PBST) was added to each well. Then, the 96-well microplate was incubated at $28^{\circ} \mathrm{C}$ for $1 \mathrm{~h}$ and washed three times with $150 \mu \mathrm{L}$ of PBST. PBST was removed, and $100 \mu \mathrm{L} /$ well TMB was added. Finally, $50 \mu \mathrm{L}$ of $\mathrm{H}_{2} \mathrm{SO}_{4}(2 \mathrm{M})$ was added after $10 \mathrm{~min}$ at $28^{\circ} \mathrm{C}$. Then, the microplate was read at $450 \mathrm{~nm}$ with a 96 -well microplate reader as soon as possible.

\subsection{RNA Isolation and Real-time Quantitative PCR (RT-qPCR)}

The fish were euthanised by anaesthetic, and the abdominal cavity was cut to obtain the spleen. Total RNA was extracted from the spleens of vaccinated fish using an RNA kit (Geneaid Co., Ltd., Taiwan) according to the manufacturer's instructions. The extracted RNA was eluted using RNase-free water, and RNA samples were aliquoted and stored at $-80{ }^{\circ} \mathrm{C}$ until use. Single-stranded cDNA was synthesised from $1 \mu \mathrm{g}$ of total RNA 
using a GoScript ${ }^{\mathrm{TM}}$ Reverse Transcriptase Kit (Promega Co., Ltd., Taiwan) following the manufacturer's instructions. Real-time quantitation was performed in an ABI StepOnePlus Real-Time PCR System (Applied Biosystems Ltd., Foster City, CA, USA) using TOOLS SYBR Green qPCR Mix (ZEJU Co., Ltd., Taiwan) following the manufacturer's recommendations. For quantitative real-time PCR, the specific primer pairs were designed as shown in Table 1 [27]. The EGF- $1 \alpha$ gene was used as a housekeeping gene, and it was amplified using EGF- $1 \alpha-\mathrm{F}$ and EGF- $1 \alpha-\mathrm{R}$ gene-specific primers. All samples were run in triplicate, and each assay was repeated three times. After finishing the programme, the threshold cycle $(\mathrm{Ct})$ values were obtained from each sample. Relative gene expression levels were evaluated using the $2^{-\Delta \Delta C T}$ method.

Table 1. Primer name, sequence, target gene and application in the present study.

\begin{tabular}{|c|c|c|c|}
\hline Name & Sequence & $\operatorname{Tm}\left({ }^{\circ} \mathrm{C}\right)$ & Reference \\
\hline $\begin{array}{l}\text { IL-1 } \beta-F \\
\text { IL-1 } \beta-R\end{array}$ & $\begin{array}{l}\text { GAGGAGCTTGGTGCAGAACA } \\
\text { CTTTGTTCGTCACCTCCTCCA }\end{array}$ & 61.4 & [27] \\
\hline $\begin{array}{l}\text { C3-F } \\
\text { C3-R }\end{array}$ & $\begin{array}{c}\text { GCATCACGCTCCTTGTCTTT } \\
\text { ACCACTATGCCACAAGAACATC }\end{array}$ & 61.4 & [27] \\
\hline $\begin{array}{l}\text { EGF1 } \alpha-F \\
\text { EGF1 } \alpha-R\end{array}$ & $\begin{array}{l}\text { CTTCTTCTGGGCCTTCTCT } \\
\text { CTTGGACGTTTCGCTGTC }\end{array}$ & 60 & this paper \\
\hline $\begin{array}{l}\text { TLR2-F } \\
\text { TLR2-R }\end{array}$ & $\begin{array}{l}\text { CTTTCTCCTCGTCCCTCTG } \\
\text { CGTGTTTGTTGTGGTCT }\end{array}$ & 60 & this paper \\
\hline $\begin{array}{l}\text { TNF- } \alpha-F \\
\text { TNF- } \alpha-R\end{array}$ & $\begin{array}{c}\text { GCGCAGTCTGTCATTGGTT } \\
\text { ACTGGACACGCTCACTGTAGTG }\end{array}$ & 60 & [27] \\
\hline
\end{tabular}

\subsection{Challenge with L. garvieae in Experiments 1 and 2}

Fish were challenged by immersion with $10^{7} \mathrm{CFU} / \mathrm{mL}$ L. garvieae on day 1 or day 32 post-vaccination. The challenged fish were observed for the next 10 and 30 days postchallenge, and mortalities were recorded daily. The relative percentage survival (RPS) was calculated according to the following formula: RPS $=(1-\%$ mortality of immunised group $/ \%$ mortality of PBS group) $\times 100 \%$.

\subsection{Statistical Analysis}

GraphPad Prism software (Version 8.0; GraphPad Software, Inc., San Diego, CA, USA) was used to generate graphs and perform statistical analyses. The results are presented as the mean $\pm \mathrm{SD}$ of three replicates. The phagocytosis, A/G ratio, antibody response and relative mRNA expression were subjected to one-way ANOVA followed by tukey's multiple comparison tests. A $p$-value $<0.05$ was considered significant. A log-rank test was used to compare the difference in survival time between the biofilm vaccine group, the whole-cell group, the chitosan particle group and the PBS group.

\section{Results}

\subsection{SEM Observation of Biofilm Formation}

Biofilms were grown on chitosan particle surfaces and were quantitated at different time points. The results show that bacteria attached to the chitosan and began to form a biofilm at $3 \mathrm{~h}$, reaching a peak at $48 \mathrm{~h}$ (Figure 2A,C). Since the correlation between biofilm $\mathrm{DMMB}$ and $\mathrm{CFU}$ was $\mathrm{R}=0.97$ at $48 \mathrm{~h}$ (data not shown), in this study we quantified the biofilm by CFU. Figure 2B shows chitosan particles without $L$. garvieae bacteria. 


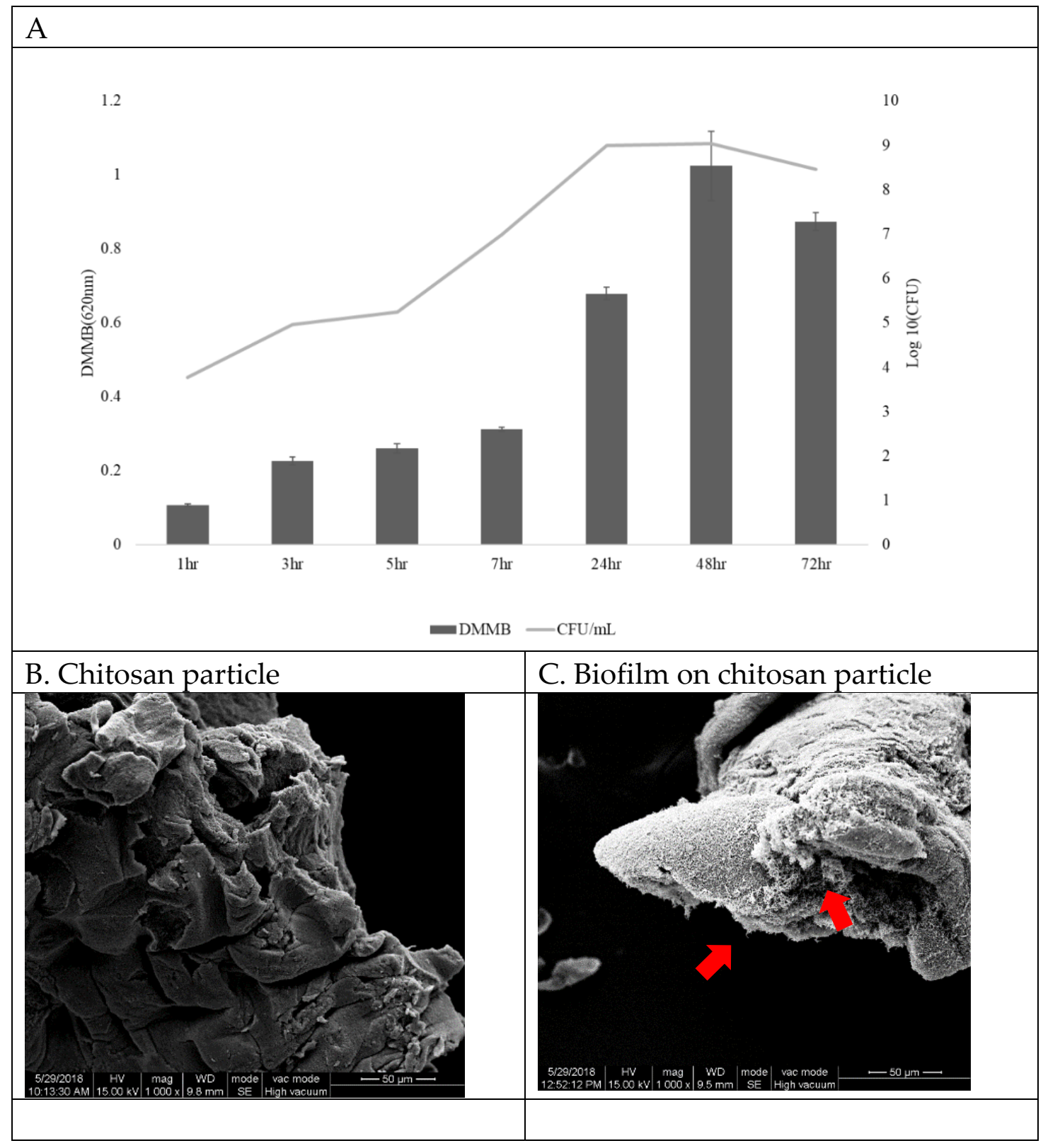

Figure 2. (A) The biofilm bacteria growth curve on chitosan particles (OD/h). L. garvieae was inoculated into BHI broth with $1 \% \mathrm{NaCl}$. The starting inoculum was $10^{4} \mathrm{CFU} / \mathrm{mL}$. From the same sample, the biofilm growth curve was quantified by the DMMB method, and CFU values were plotted to obtain the bacteria growth curve. The biofilm growth abilities were evaluated by determining the optical density (OD) after applying the DMMB method (from time $=0$ to time $=72 \mathrm{~h}$ ). Data are presented as mean $\pm \mathrm{SD}(n=4)$. Scanning electron micrographs of $(\mathbf{B})$ chitosan particle surface without L. garvieae growth and (C) biofilm growth on a chitosan particle at $48 \mathrm{~h}$ (arrows: L. garvieae biofilm). Magnification: $1000 \times ;$ bars $=50 \mu \mathrm{m}$.

\subsection{Confirmation of Adsorbed Biofilm Antigen in Intestine, Head Kidney and Spleen via Immunohistochemistry}

Black mullets were orally administered the biofilm vaccine, and the antigen was detected by IHC. No signal was detected in the PBS group (Figure $3 \mathrm{~A}, \mathrm{C}, \mathrm{E}$ ), while the group that received the biofilm vaccine displayed signals in the intestine, head kidney and spleen tissues (Figure 3B,D,F). 


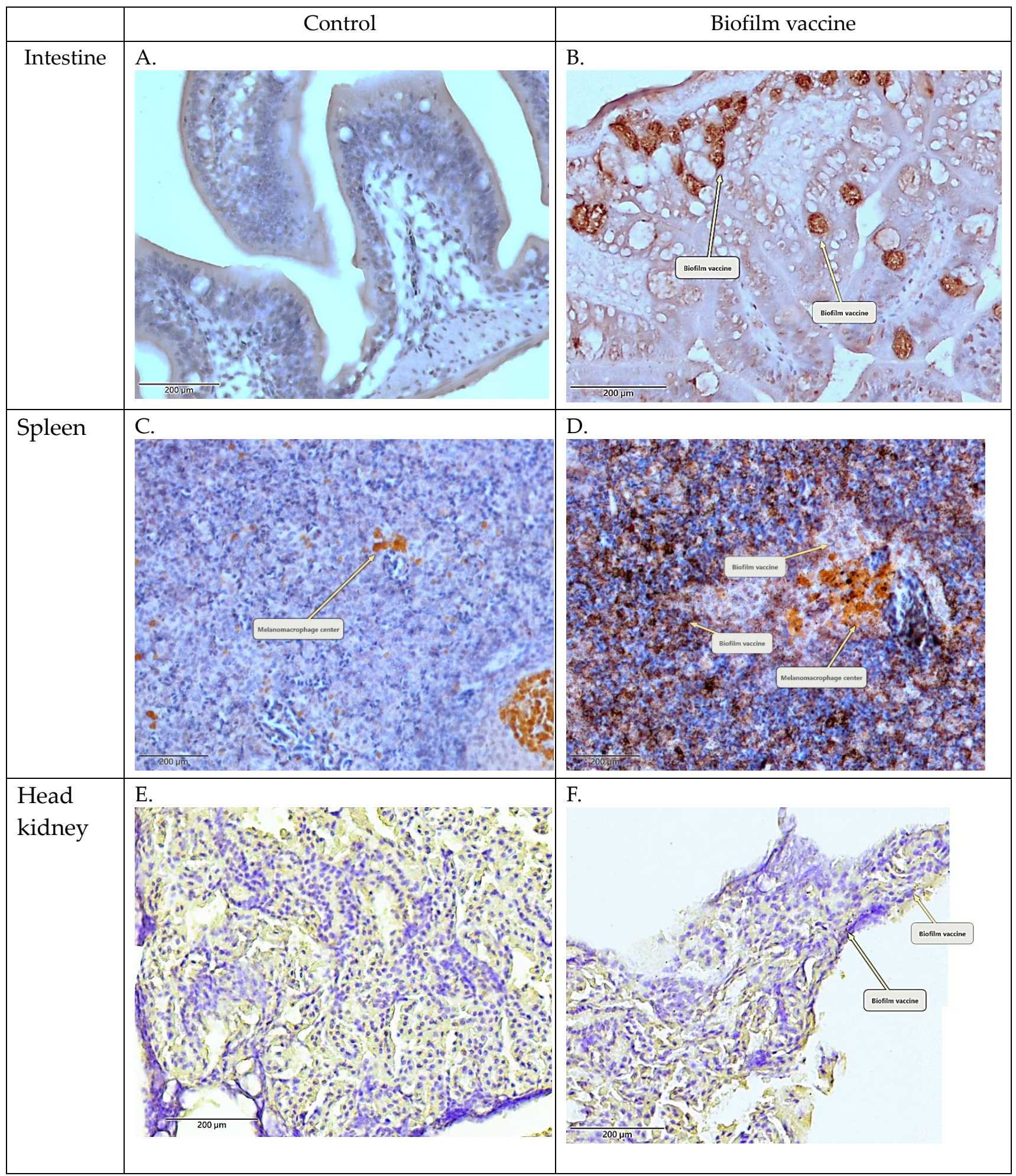

Figure 3. Immunohistochemical (IHC) staining of the head kidney and intestine collected after vaccination. (A,C,E) PBS control. $(\mathbf{B}, \mathbf{D}, \mathbf{F})$ Biofilm vaccine group $(\mathrm{mag} . \times 400)$. Arrows indicate positive signals and melanomacrophage centres.

\subsection{Innate Immune Response after Vaccination}

After the vaccines and control diets were orally administered to the black mullets, the immune responses of experimental fish were evaluated by measuring phagocytic ability and $A / G$ ratios. The results indicate that the phagocytic ability of the biofilm vaccine group $(84 \%)$ was significantly higher than that of the whole-cell vaccine, chitosan particle and PBS 
groups (66\%, 65\% and 59\%, respectively) (Figure $4 \mathrm{~A})$. The A/G ratio was also increased in the biofilm vaccine group (0.56) compared to the other three groups $(0.34,0.42$ and 0.32 , respectively) (Figure $4 \mathrm{~B}$ ).
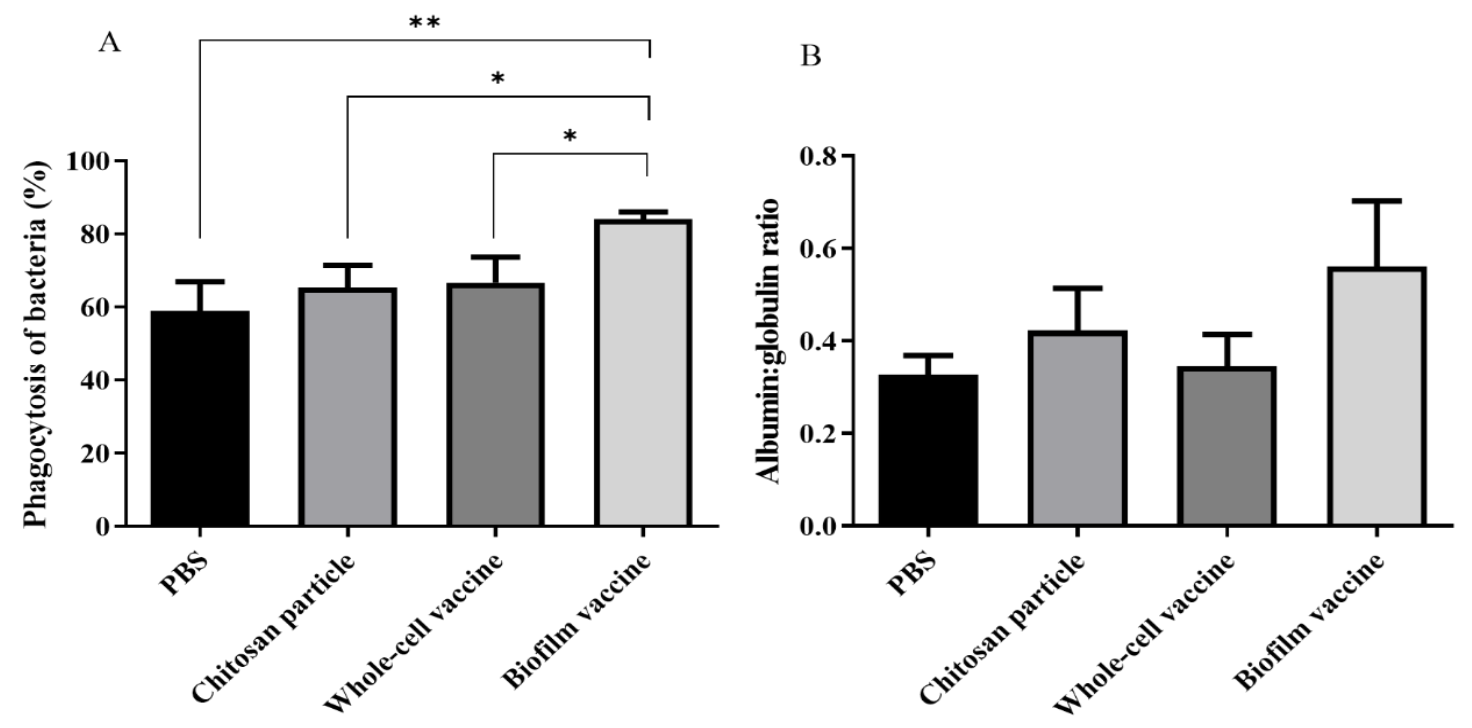

Figure 4. (A) Phagocytic activity of whole blood with different types of vaccine. The biofilm vaccine group had significantly increased phagocytic activity compared to PBS and whole-cell vaccine groups. Data are presented as mean \pm SD ( $n=3$ fish $\times 3$ replicates per treatment). $p$-values were calculated by one-way ANOVA $\left(p<0.01 * *, p<0.05^{*}\right)$. (B) Albuminglobulin ratios of plasma with different vaccines. Data are presented as mean $\pm \operatorname{SD}(n=3$ fish $\times 3$ replicates per treatment). The $p$-values indicate that there were no significant differences between groups.

\subsection{Antibody Production}

In order to evaluate the antibody response against biofilm and whole-cell bacteria after vaccination, $10^{7}$ (CFU/well) whole cells or biofilms were coated in 96-well plates with serum and used to measure IgM titres. The anti-L. garvieae biofilm IgM titre in the biofilm vaccine group was significantly higher than those in PBS and whole-cell groups $(p<0.05)$ (Figure 5A). The OD450 value of the biofilm vaccine group was 0.22 , and those of the chitosan particle, whole-cell vaccine and PBS groups were respectively $0.19,0.18$ and 0.18 . In addition, the anti-L. garvieae whole-cell IgM titre in the biofilm vaccine group was significantly higher than those in the PBS and whole-cell groups $(p<0.05)$ (Figure 5B). The OD450 value in the biofilm vaccine group was 0.218 , and those in the chitosan particle, whole-cell vaccine and PBS groups were 0.19, 0.195 and 0.184 .

\subsection{Immune-Related Gene Analysis}

After vaccination, mRNA was extracted from the spleen and analysed for immunerelated gene expression, including interleukin $1 \beta$ (IL-1 $\beta$ ), toll-like receptor 2 (TLR2), tumour necrosis factor- $\alpha$ (TNF- $\alpha$ ) and complement component 3 (C3). The relative expression analysis showed that the mRNA expression levels of IL- $1 \beta$, TLR2 and TNF- $\alpha$ genes were significantly increased $(p<0.05)$ in the biofilm vaccine group when compared to the PBS group. TNF- $\alpha$ expression in the biofilm vaccine group was 7.86 times higher than that in the PBS group, and its expression in the whole-cell vaccine and chitosan particle groups was 2.6 and 0.1 times higher than that in the PBS group (Figure 6A). The expression of the C3 gene was higher in the vaccine groups, but the difference was not significant (Figure 6B). IL-1 $\beta$ expression in the biofilm vaccine group was 3.4 times higher than that in the PBS group, and its expression in the whole-cell vaccine and chitosan particle groups was 1.6 and 1.1 times higher than that in the PBS group (Figure 6C). TLR2 expression in the biofilm vaccine group was 2.4 times higher than that in the PBS group, and its expression in the whole-cell vaccine and chitosan particle groups was 0.5 and 1.3 times higher than that in 
the PBS group (Figure 6D). Overall, the results show that pro-inflammatory-related gene expression in the oral biofilm vaccine group was significantly increased compared to that in the other groups.
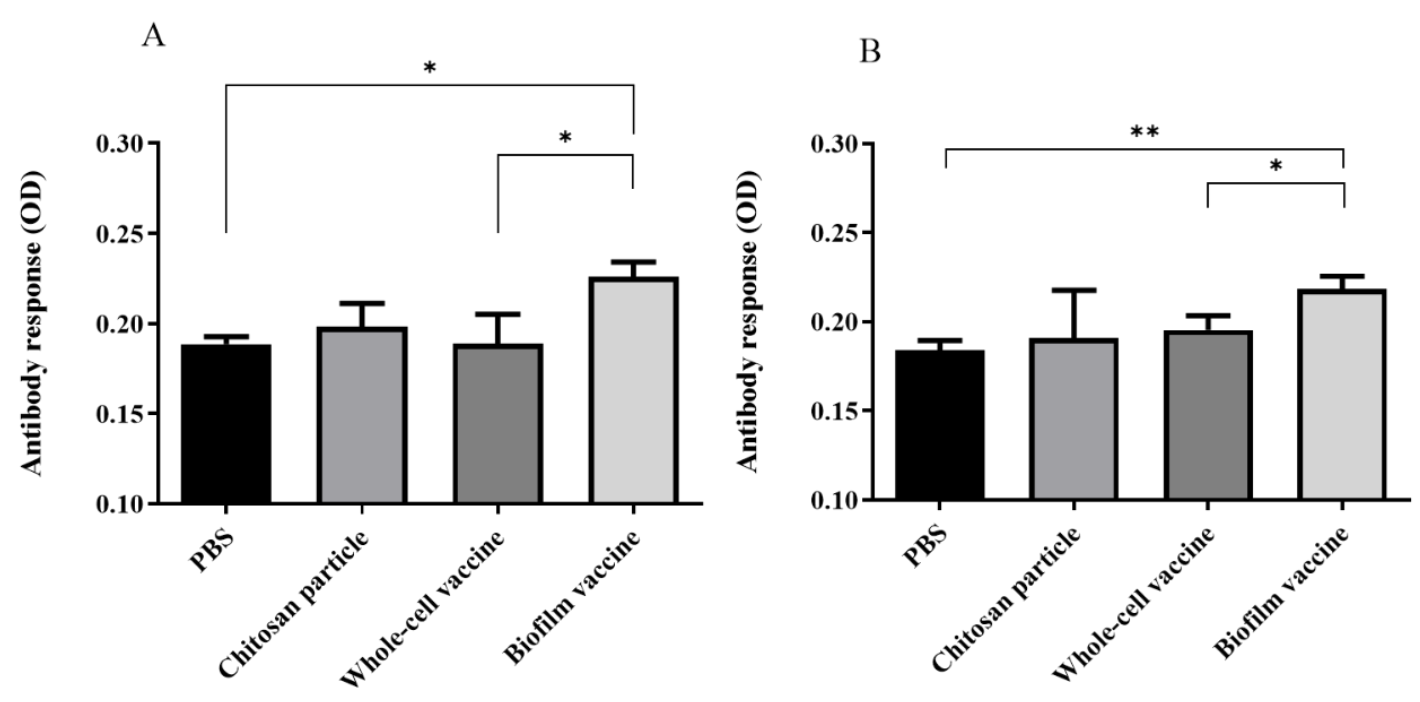

Figure 5. Serum IgM titres of fish vaccinated with different vaccines. The biofilm vaccine group had significantly increased IgM titres compared to the PBS and whole-cell vaccine groups. (A) Biofilm antigen coating on 96-well microplate. (B) Whole-cell antigen coating on 96-well microplate. Data are presented as mean \pm SD $(n=3$ fish $\times 3$ replicates per treatment). $p$-values were calculated by one-way ANOVA $\left(p<0.01^{* *}, p<0.05^{*}\right)$.

\subsection{Relative Percentage Survival}

Black mullets were orally administered different vaccines daily for 14 days and then challenged with $10^{7} \mathrm{CFU} / \mathrm{mL}$ L. garvieae. The death of fish was observed, starting at 3 days after the challenge and increasing gradually. Nine days after the L. garvieae challenge, the survival rates for the groups administered feed with the biofilm vaccine, whole-cell vaccine, chitosan particles and PBS were respectively $75 \%, 45 \%, 30 \%$ and $5 \%$ (Figure 7 ), and the differences were significant. The relative percent survival (RPS) was $74 \%, 42 \%$ and $26 \%$ for the biofilm vaccine, whole-cell vaccine and chitosan particle groups, respectively (Table 2).

\subsection{Long-Term Analysis of Serum Antibody Titres and Relative Percentage Survival}

The biofilm vaccine group showed a significant increase $(p<0.01)$ in IgM titres compared to the other groups at 7, 14, 21, 32, 70 and 100 days post-vaccination. The IgM titre peak was observed at 14 days post-vaccination in the biofilm vaccine group and was significantly higher than those in the other groups on days 7, 14, 21, 32 and 70 . The IgM titres of the chitosan group was slightly increased on days 7, 14, 21 and 32, but no significant changes were observed throughout the study period. The IgM titres of the whole-cell group slightly increased on days 7, 14, 21, 32 and 70, but no significant changes were observed throughout the study period. The PBS group showed no significant changes in antibody levels throughout the study period (Figure 8). The experimental fish were challenged with L. garvieae at 32 days post-vaccination. Survival rates in the biofilm vaccine, whole-cell vaccine, chitosan particle and PBS groups were $80 \%, 28 \%, 13 \%$ and $12 \%$ at 30 days after L. garvieae challenge, respectively, and the differences were significant (Figure 9). The RPS was $77 \%, 18 \%$ and $0 \%$ for the biofilm vaccine, whole-cell vaccine and chitosan particle groups, respectively (Table 3 ). 

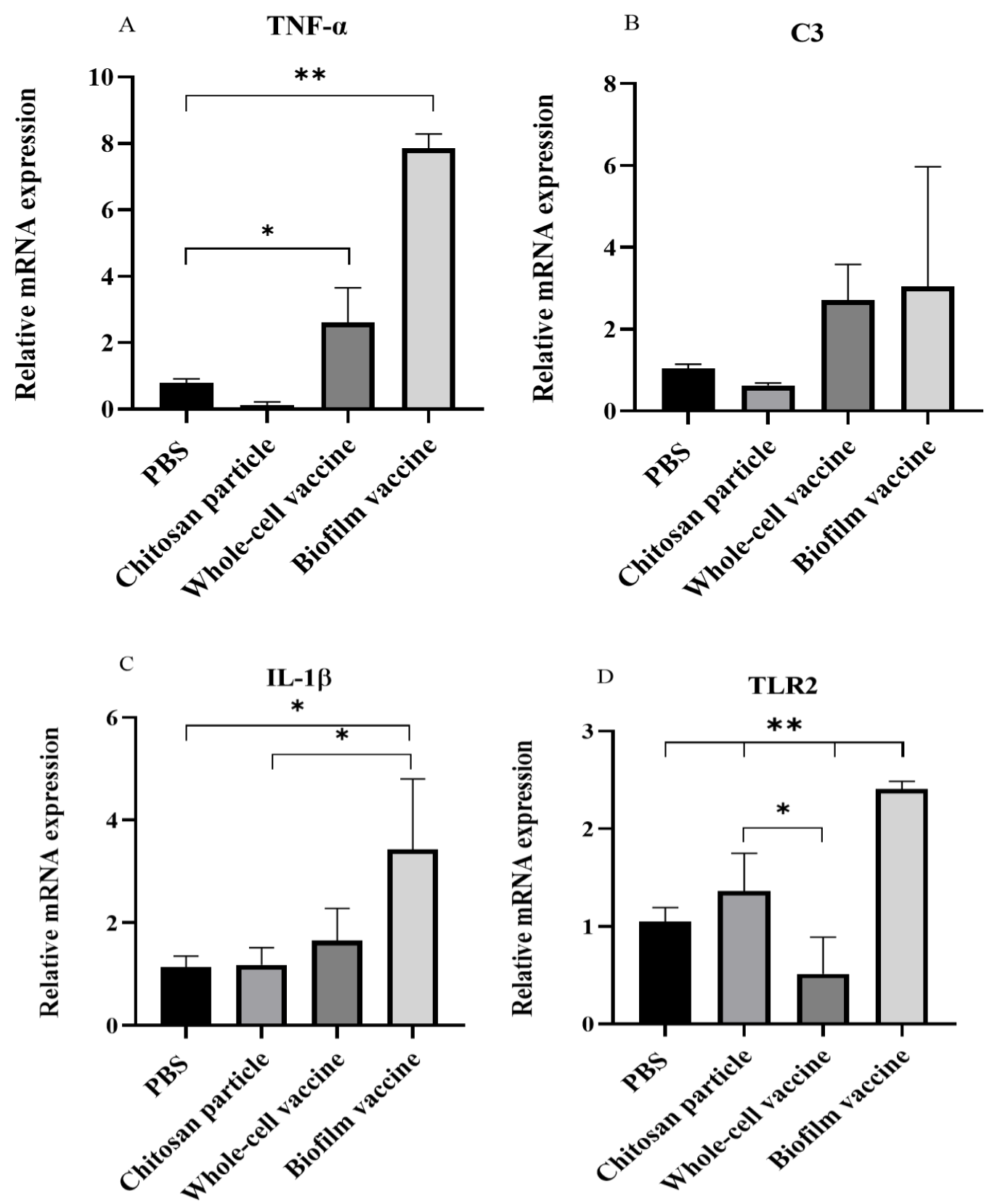

Figure 6. Expression levels of (A) TNF- $\alpha$ (B) C3, (C) IL-1 $\beta$ and (D) TLR2 in spleen samples $(n=3$ fish spleen samples $\times 3$ replicates per treatment) after vaccination in each group. Data are presented as mean $\pm \mathrm{SD}$, and $p$-values were calculated by one-way ANOVA $\left(p<0.05^{*}, p<0.01^{* *}\right)$. 


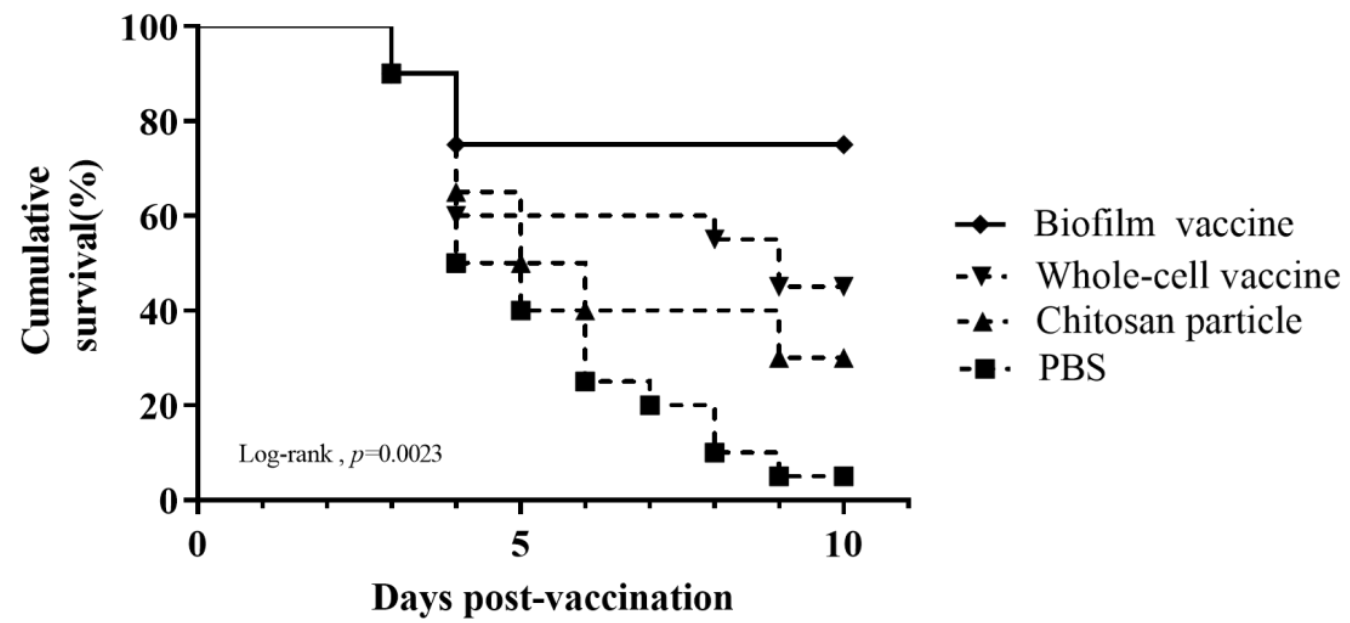

Figure 7. Cumulative survival rate in challenge experiment 1 . The mullets were challenged by immersion with $10^{7} \mathrm{CFU} / \mathrm{mL}$ of Lactococcus garvieae. Challenge was performed on day 1 after vaccination. Fish were monitored for 10 days. Statistical significance was determined by the logrank test; there were significant differences between groups $(p=0.0023)$.

Table 2. Relative percent survival (RPS) in vaccinated mullet.

\begin{tabular}{cccc}
\hline Group & & Final Mortality (\%) & RPS (\%) \\
\hline Biofilm vaccine & $n=20$ & 25 & 74 \\
Whole-cell vaccine & $n=20$ & 55 & 42 \\
Chitosan particle & $n=20$ & 70 & 26 \\
PBS & $n=20$ & 95 & \\
\hline
\end{tabular}

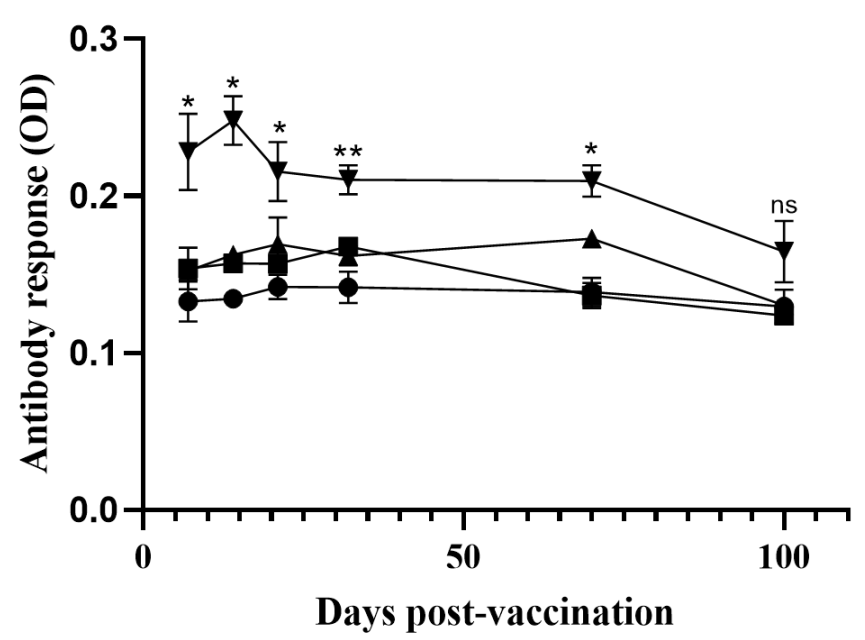

$\rightarrow$ PBS

- Chitosan particle

$\star$ Whole-cell vaccine

$\rightarrow$ Biofilm vaccine

Figure 8. Long-term analysis of challenge experiment 2. Serum antibody levels of fish vaccinated with different vaccines. Data are presented as mean $\pm \mathrm{SD}(n=3$ fish $\times 3$ replicates per treatment). $p$-values were calculated by one-way ANOVA. Data are significantly different $\left(p<0.05^{*}, p<0.01^{* *}\right)$. 


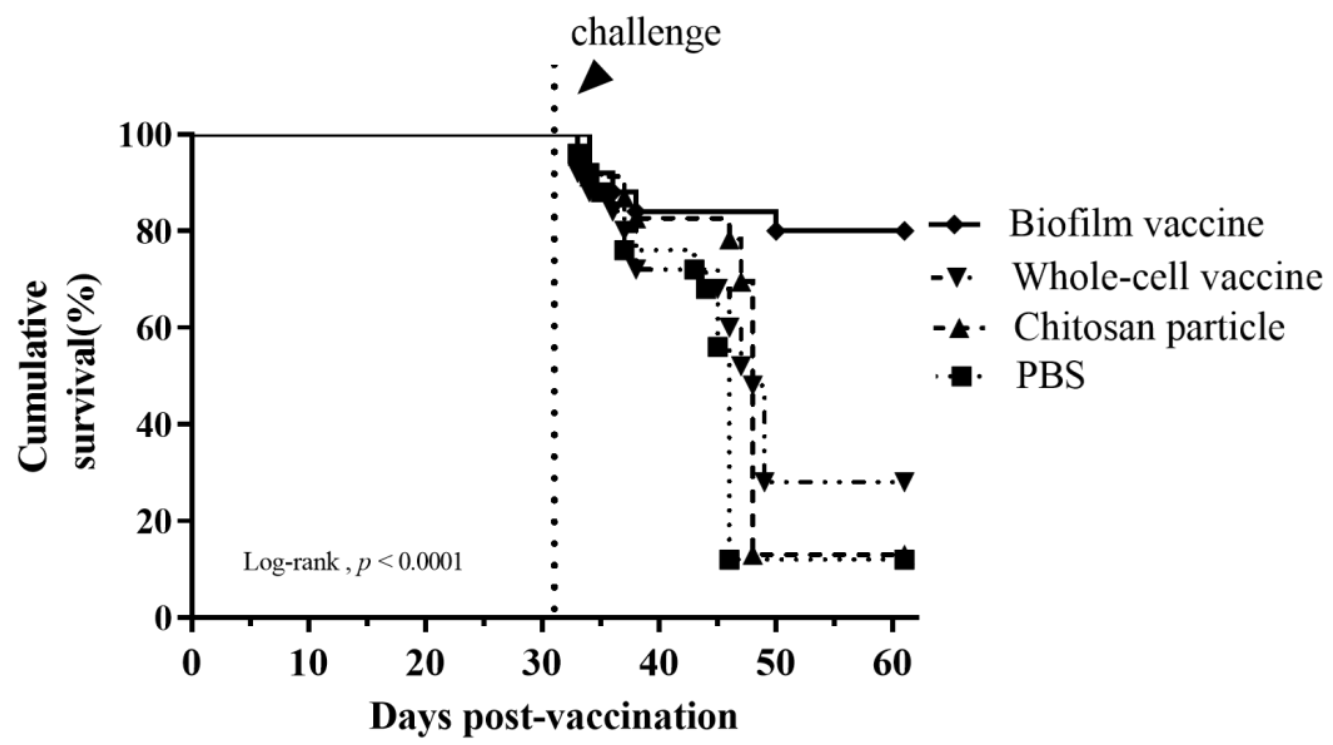

Figure 9. Long-term analysis of relative percentage survival in challenge experiment 2. Cumulative survival rate of the experimental mullet challenged by immersion with $10^{7} \mathrm{CFU} / \mathrm{mL}$ of Lactococcus garvieae. Challenge was performed on day 32 post-vaccination. Fish were monitored for 30 days. Statistical significance was determined by the log-rank test; there were significant differences between groups $(p<0.0001)$.

Table 3. Relative percent survival (RPS) in vaccinated mullet.

\begin{tabular}{cccc}
\hline Group & & Final Mortality (\%) & RPS (\%) \\
\hline Biofilm vaccine & $n=25$ & 20 & 77 \\
Whole-cell vaccine & $n=25$ & 72 & 18 \\
Chitosan particle & $n=25$ & 88 & 0 \\
PBS & $n=25$ & 88 & \\
\hline
\end{tabular}

\section{Discussion}

L. garvieae causes high mortality in aquaculture fish in Taiwan, especially in summer. We believe that the recurrence of streptococcosis is due to biofilm formation, causing chronic infection [28]. Biofilm provides a stable environment for L. garvieae, from which it can spread to other tissues, resulting in reinfection. A previous study showed that wholecell counterparts—-that is, bacteria living in biofilms—-have a developmental evolutionary advantage in comparison to planktonic cells because they are less sensitive to antibiotics, which complicates the effectiveness of antimicrobial therapy. Moreover, biofilm formation leads to inflammatory response inhibition, antibody neutralisation and macrophage phagocytosis [29-31]. In order to solve the problem of long-term chronic infections, researchers have recently begun to develop oral biofilm vaccines against a diverse range of biofilm antigens. However, although biofilm is easy to culture, it is difficult to mass produce for the preparation of vaccines. The earliest biofilm collection method used chitin flakes, but this procedure is complicated and time-consuming [15]. In this study, we used chitosan particles to provide an adherence platform for cultured bacterial biofilm in suspension. In addition to this function, chitosan is an immune stimulant and can be used as an adjuvant in fish [32]. In our experiments, we observed that $L$. garvieae biofilm formation was detectable on chitosan particles at $3 \mathrm{~h}$. At $48 \mathrm{~h}$, the largest amount of L. garvieae biofilm was observed on chitosan particles via SEM, and the observations were in agreement with the results of the DMMB method used to create the growth curves of biofilm (Figure 2A).

Oral administration is the simplest method for vaccination in aquaculture. It was previously revealed in salmon that oral vaccination can induce the production of antibodies 
with protective efficacy [33]. The oral administration of vaccines and adjuvants (e.g., oilbased and aluminium-based adjuvants) has been reported to induce mucosal immunity, particularly in the gut, and to achieve a good protective effect [34-37] because of the resistance to gastric acid [38-40]. L. garvieae survives at $\mathrm{pH} 2-9$ and is resistant to extreme environments [41]. Therefore, when our oral biofilm vaccine passes through stomach acid, it is not destroyed and can be absorbed by intestinal epithelial cells. In our study, IHC staining detected the oral biofilm vaccine antigen in the intestine, head kidney and spleen. Strong signals were observed in the small intestine and spleen (Figure 3). This indicates that our biofilm vaccine can be effectively delivered to the immune tissues of the fish.

Phagocytic capacity and A/G ratio are important parameters of the innate immune response. Our results show that mullet fish are able to mount an immune response against L. garvieae bacteria after vaccination. The phagocytic ability in the biofilm group was $84 \%$, and the $\mathrm{A} / \mathrm{G}$ ratio was 0.56 , which values are higher than those in the other groups. However, the phagocytic ability in the whole-cell group was $66 \%$ and the $\mathrm{A} / \mathrm{G}$ ratio was 0.34 , which values are not significantly higher than those in the other groups. In addition, the chitosan particle group had a phagocytic ability of $65 \%$ and an $A / G$ ratio of 0.42 . The same findings were reported in a previous study by Ranjan et al., who found that feeding chitosan increased the phagocytic capacity and A/G ratio of seabass [42]. Therefore, we hypothesise that chitosan particles might also act as an adjuvant for biofilm vaccines to enhance the innate immunity of mullet fish.

TLRs contribute to the recognition of pathogen-associated molecular patterns (PAMPs) and activate immune cells in response to infection through signalling pathways. TLR2, one member of the TLR family, has a highly conserved structure involved in detecting the cell walls of Gram-positive bacteria, and the TLR2 activation signalling pathway induces the expression of TLR2 and cytokines such as IL-1 $\beta$ and TNF- $\alpha$ [43,44]. In the relative mRNA expression study, TLR2, IL-1 $\beta$ and TNF- $\alpha$ mRNA were significantly increased in the oral biofilm vaccine group. The expression of TNF- $\alpha$ mRNA was significantly upregulated in the whole-cell vaccine group, but TLR2 gene expression was lower than that in the PBS, whole-cell and biofilm vaccine groups. The expression of TLR2 and IL-1 $\beta$ was increased, but not significantly, in the chitosan particle group. IL-1 $\beta$ has been shown to enhance antibody production when administered with bacterial vaccines, suggesting that it might be effectively exploited as an immune adjuvant to improve vaccine efficacy [45]. In Mycobacterium marinum-infected zebrafish, TNF- $\alpha$ was shown to promote macrophage phagocytosis and restrict bacterial growth in infected macrophages [46]. In the complement system (C3), although there was an average difference, it was not significant. According to Rao et al., the expression of IL- $1 \beta$, TNF- $\alpha$ and C 3 complement genes increased after the injection of a Lactococcus garvieae bacterial vaccine [47]. Although the methods and types of vaccines are different, the pro-inflammatory response also increased in this study. Therefore, the biofilm vaccine group induced a pro-inflammatory response through IL$1 \beta$ and TNF- $\alpha$ gene expression via the TLR2 signal transduction pathway, enhanced the production of antibodies, and increased the phagocytic ability of macrophages.

Antibody production is an important index to evaluate vaccine efficacy. In previous oral vaccines research, when antigens were delivered via the gut, local and systemic immune responses were elicited, indicated by high amounts of circulating IgM [48]. In the present study, the results after biofilm vaccine administration revealed significantly increased IgM against biofilm antigen or whole-cell antigen (Figure 5). No significant antibody production was observed in the chitosan particle or whole-cell vaccine groups. Biofilm vaccines incorporate a variety of antigens, including whole cells. This also shows that oral biofilm vaccines can produce anti-whole-cell antibodies, but whole-cell vaccines may be present in insufficient amounts in the feed to produce more antibodies.

After vaccination, we monitored the production of fish antibodies for 100 days. The IgM level in the biofilm vaccine group was significantly different from that in the PBS group. Antibody production was observed on days 7, 14, 21, 32, 70 and 100. However, the chitosan particle and whole-cell vaccine groups did not display significant differences in 
the production of antibodies. We conclude that the biofilm vaccine stimulated long-term anti-L. garvieae antibody production an immune response that is transferred from GALT to systemic over a long period. In studies of Pseudomonas putida and Streptococcus agalactiae biofilm vaccines, the same enhancement in antibody production was also found [18,49].

In challenge experiments 1 and 2, the RPS values were $74 \%$ and $77 \%$ for the biofilm vaccine group, $42 \%$ and $18 \%$ for the whole-cell vaccine group and $26 \%$ and $0 \%$ for the chitosan particle group, respectively. According to the cumulative survival rates in these two challenge experiments, the survival rates of whole-cell vaccine and chitosan particle groups decreased sharply, showing reduced long-term protective efficacy after bacteria challenge (Table 3) and suggesting limited applicability. Our results demonstrate that the oral administration of the biofilm vaccine triggered IgM antibody production, and the protective effect against the infection of $L$. garvieae lasted for at least 70 days postvaccination. Most studies on biofilm vaccines have focused on vaccines against $A$. hydrophila. In a previous study on an $A$. hydrophila oral vaccine, fish were fed biofilm (BF) and free cell (FC) vaccines against $A$. hydrophila at $10^{10}$ cells/g fish/day for 20 days. Upon challenge with $A$. hydrophila at $10^{9} \mathrm{CFU} / \mathrm{mL}$, BF-vaccinated fish had a significantly higher relative percent survival $(88 \%)$ than the FC-treated fish $(29.6 \%)$ at 60 days post-vaccination [50]. A recent study of an inactivated L. garvieae oral vaccine with chitosan-alginate capsules reported an RPS of $66.67 \pm 5.77 \%$ compared to the control group [51].

\section{Conclusions}

In this study, we developed a novel, effective, orally administered chitosan particle biofilm vaccine, which conferred effective protection against Lactococcus garvieae in mullet fish. The L. garvieae oral biofilm vaccine significantly increased specific antibody titres, enhanced phagocytosis, and induced pro-inflammatory gene expression. Although the L. garvieae biofilm vaccine had favourable protective effects in grey mullet, the detailed mechanism of the oral vaccine is still not understood and should be explored in future investigations. This study provides a novel method for the further development of vaccines that are convenient and more applicable to the aquaculture industry.

Author Contributions: F.-J.S. contributed to methodology, investigation, data curation, formal analysis, data analysis and software. M.-M.C. thoroughly edited the manuscript. All authors have read and agreed to the published version of the manuscript.

Funding: This work was funded by the Animal and Plant Health Inspection and Quarantine Bureau of the Agriculture Committee of the Executive Yuan (Grant No.107MG-8.3.2-B1(2)). This article was subsidised for English editing by National Taiwan University under the Excellence Improvement Program for Doctoral Students (Grant No. 108-2926-I-002-002-MY4), sponsored by the Ministry of Science and Technology, Taiwan.

Institutional Review Board Statement: This study was conducted according to the guidelines of the Regulation on the Use of Animals in Research and approved by the Animal Care Use Committee of the National Taiwan University (protocol no. B201800003).

Informed Consent Statement: Not applicable.

Data Availability Statement: The data presented in this study are available in this article.

Acknowledgments: We thanks anonymous reviewer for useful comments on this manuscript, and Peiy-ing Wu and Yi-Chun Chuang from the Technology Commons, College of Life Science, NTU for the excellent technical assistance on scanning electron microscopy (SEM) and fluorescence microscopy.

Conflicts of Interest: The authors declare no conflict of interest.

\section{References}

1. Vendrell, D.; Balcazar, J.L.; Ruiz-Zarzuela, I.; de Blas, I.; Girones, O.; Muzquiz, J.L. Lactococcus garvieae in fish: A review. Comp. Immunol. Microbiol. Infect. Dis. 2006, 29, 177-198. [CrossRef]

2. Evans, J.J.; Klesius, P.H.; Shoemaker, C.A. First isolation and characterization of Lactococcus garvieae from Brazilian Nile tilapia, Oreochromis niloticus (L.), and pintado, Pseudoplathystoma corruscans (Spix \& Agassiz). J. Fish Dis. 2009, 32, $943-951$. 
3. Chen, S.C.; Liaw, L.L.; Su, H.Y.; Ko, S.C.; Wu, C.Y.; Chaung, H.C.; Tsai, Y.H.; Yang, K.L.; Chen, Y.C.; Chen, T.H.; et al. Lactococcus garvieae, a cause of disease in grey mullet, Mugil cephalus L., in Taiwan. J. Fish Dis. 2002, 25, 727-732. [CrossRef]

4. Parsek, M.R.; Singh, P.K. Bacterial Biofilms: An Emerging Link to Disease Pathogenesis. Annu. Rev. Microbiol. 2003, 57, 677-701. [CrossRef] [PubMed]

5. Le, Y.K.; Park, M.D.; Otto, M. Immune evasion mechanisms of Staphylococcus epidermidis biofilm infection. Front. Microbiol. 2018, 9, 359. [CrossRef] [PubMed]

6. Watters, C.; Fleming, D.; Bishop, D.; Rumbaugh, K. Host responses to biofilm. Prog. Mol. Biol. Transl. Sci. 2016, 142, 193-239. [PubMed]

7. Sanchez, C.J.; Hurtgen, B.J.; Lizcano, A.; Shivshankar, P.; Cole, G.T.; Orihuela, C.J. Biofilm and planktonic pneumococci demonstrate disparate immunoreactivity to human convalescent sera. BMC Microbiol. 2011, 11, 245. [CrossRef]

8. Loera-Muro, A.; Guerrero-Barrera, A.; Tremblay DN, Y.; Hathroubi, S.; Angulo, C.J.E.R.o.V. Bacterial biofilm-derived antigens: A new strategy for vaccine development against infectious diseases. Expert Rev. Vaccines 2021, 1-15.

9. Mckenney, D.; Pouliot, K.; Wang, Y.; Murthy, V.; Ulrich, M.; Döring, G.; Lee, J.C.; Goldmann, D.A.; Pier, G.B. Vaccine potential of poly-1-6 $\beta$-DN-succinylglucosamine, an immunoprotective surface polysaccharide of Staphylococcus aureus and Staphylococcus epidermidis. J. Biotechnol. 2000, 83, 37-44. [CrossRef]

10. Corsini, B.; Aguinagalde, L.; Ruiz, S.; Domenech, M.; Antequera, M.L.; Fenoll, A.; García, P.; García, E.; Yuste, J.J.V. Immunization with LytB protein of Streptococcus pneumoniae activates complement-mediated phagocytosis and induces protection against pneumonia and sepsis. Vaccine 2016, 34, 6148-6157. [CrossRef]

11. Forchielli, M.L.; Walker, W.A. The role of gut-associated lymphoid tissues and mucosal defence. Br. J. Nutr. 2005, 93, S41-S48. [CrossRef]

12. Azad, I.; Shankar, K.; Mohan, C.; Kalita, B.J.D.o.a.o. Uptake and processing of biofilm and free-cell vaccines of Aeromonas hydrophila in Indian major carps and common carp following oral vaccination antigen localization by a monoclonal antibody. Dis. Aquat. Org. 2000, 43, 103-108. [CrossRef] [PubMed]

13. Vinay, T.; Girisha, S.; D'souza, R.; Jung, M.-H.; Choudhury, T.; Patil, S.S. Bacterial biofilms as oral vaccine candidates in aquaculture. Indian J. Comp. Microbiol. Immunol. Infect. Dis. 2016, 37, 57. [CrossRef]

14. Rombout, J.; Kiron, V.J.F.v. Mucosal vaccination of fish. In Fish Vaccination; Blackwell: Chichester, UK, $2014 ;$ pp. 56-67.

15. Azad, I.; Shankar, K.; Mohan, C.; Kalita, B. Biofilm vaccine of Aeromonas hydrophila-standardization of dose and duration for oral vaccination of carps. Fish Shellfish. Immunol. 1999, 9, 519-528. [CrossRef]

16. Nayak, D.; Asha, A.; Shankar, K.; Mohan, C.J.F. Evaluation of biofilm of Aeromonas hydrophila for oral vaccination of Clarias batrachus-A carnivore model. Fish Shellfish. Immunol. 2004, 16, 613-619. [CrossRef] [PubMed]

17. Kaur, B.; Kumar, B.N.; Tyagi, A.; Holeyappa, S.A.; Singh, N.K.J.F. Identification of novel vaccine candidates in the wholecell Aeromonas hydrophila biofilm vaccine through reverse vaccinology approach. Fish Shellfish. Immunol. 2021, 114, 132-141. [CrossRef]

18. Kahieshesfandiari, M.; Sabri, M.; Ina-Salwany, M.; Hassan, M.; Noraini, O.; Ajadi, A.; Isiaku, A. Streptococcosis in Oreochromis sp.: Is feed-based biofilm vaccine of Streptococcus agalactiae effective? Aquac. Int. 2019, 27, 817-832. [CrossRef]

19. Ram, M.K.; Kumar, B.N.; Poojary, S.R.; Abhiman, P.; Patil, P.; Ramesh, K.; Shankar, K.J.F. Evaluation of biofilm of Vibrio anguillarum for oral vaccination of Asian seabass, Lates calcarifer (BLOCH, 1790). Fish Shellfish. Immunol. 2019, 94, 746-751. [CrossRef]

20. Kitiyodom, S.; Trullàs, C.; Rodkhum, C.; Thompson, K.D.; Katagiri, T.; Temisak, S.; Namdee, K.; Yata, T.; Pirarat, N.J.F. Modulation of the mucosal immune response of red tilapia (Oreochromis sp.) against columnaris disease using a biomimetic-mucoadhesive nanovaccine. Fish Shellfish. Immunol. 2021, 112, 81-91. [CrossRef]

21. Kitiyodom, S.; Yata, T.; Yostawornkul, J.; Kaewmalun, S.; Nittayasut, N.; Suktham, K.; Surassmo, S.; Namdee, K.; Rodkhum, C.; Pirarat, N.J.F.; et al. Enhanced efficacy of immersion vaccination in tilapia against columnaris disease by chitosan-coated "pathogen-like" mucoadhesive nanovaccines. Fish Shellfish. Immunol. 2019, 95, 213-219. [CrossRef]

22. Zlotkin, A.; Eldar, A.; Ghittino, C.; Bercovier, H. Identification of Lactococcus garvieae by PCR. J. Clin. Microbiol. 1998, 36, 983-985. [CrossRef] [PubMed]

23. Oushani, A.K.; Soltani, M.; Sheikhzadeh, N.; Mehrgan, M.S.; Islami, H.R.J.F. Effects of dietary chitosan and nano-chitosan loaded clinoptilolite on growth and immune responses of rainbow trout (Oncorhynchus mykiss). Fish Shellfish. Immunol. 2020, 98, 210-217. [CrossRef]

24. Tote, K.; Berghe, D.V.; Maes, L.; Cos, P. A new colorimetric microtitre model for the detection of Staphylococcus aureus biofilms Lett. Appl. Microbiol. 2007, 46, 249-254. [CrossRef]

25. Park, H.K.; Jeong, H.D. Enhanced resistance against Edwardsiella tarda infection in tilapia (Oreochromis niloticus) by administration of protein-bound polysaccharide. Aquaculture 1996, 143, 135-143. [CrossRef]

26. Thanga Viji, V.; Deepa, K.; Velmurugan, S.; Donio, M.B.; Adlin Jenifer, J.; Babu, M.M.; Citarasu, T. Vaccination strategies to protect goldfish Carassius auratus against Aeromonas hydrophila infection. Dis. Aquat. Org. 2013, 104, 45-57. [CrossRef]

27. Byadgi, O.; Chen, Y.-C.; Barnes, A.C.; Tsai, M.-A.; Wang, P.-C.; Chen, S.-C.J.F. Transcriptome analysis of grey mullet (Mugil cephalus) after challenge with Lactococcus garvieae. Fish Shellfish. Immunol. 2016, 58, 593-603. [CrossRef]

28. Benton, A.K.; Everson, M.P.; Briles, D.E. A pneumolysin-negative mutant of Streptococcus pneumoniae causes chronic bacteremia rather than acute sepsis in mice. Infect. Immun. 1995, 63, 448-455. [CrossRef] [PubMed]

29. Stewart, S.P.; Costerton, J.W. Antibiotic resistance of bacteria in biofilms. Lancet 2001, 358, 135-138. [CrossRef] 
30. Thurlow, L.R.; Hanke, M.L.; Fritz, T.; Angle, A.; Aldrich, A.; Williams, S.H.; Engebretsen, I.L.; Bayles, K.W.; Horswill, A.R.; Kielian, T. Staphylococcus aureus biofilms prevent macrophage phagocytosis and attenuate inflammation in vivo. J. Immunol. 2011, 186, 6585-6596. [CrossRef]

31. Costerton, J.W.; Cheng, K.; Geesey, G.G.; Ladd, T.I.; Nickel, J.C.; Dasgupta, M.; Marrie, T.J.J.A.R.i.M. Bacterial biofilms in nature and disease. Annu. Rev. Microbiol. 1987, 41, 435-464. [CrossRef] [PubMed]

32. Anderson, D.P. Adjuvants and immunostimulants for enhancing vaccine potency in fish. Dev. Boil. Stand. 1997, 90, 257-265.

33. Wong, G.; Kaattari, S.L.; Christensen, J.M. Effectiveness of an oral enteric coated vibrio vaccine for use in salmonid fish. Immunol. Investig. 1992, 21, 353-364. [CrossRef]

34. Jenkins, P.; Wrathmell, A.; Harris, J.; Pulsford, A. The effects of different adjuvants on intestinal antigen absorption and subsequent immune responses of the tilapian Oreochromis mossambicus. Fish Shellfish. Immunol. 1994, 4, 167-177. [CrossRef]

35. Davidson, G.; Ellis, A.; Secombes, C. Route of immunization influences the generation of antibody secreting cells in the gut of rainbow trout (Oncorhynchus mykiss). Dev. Comp. Immunol. 1993, 17, 373-376. [CrossRef]

36. Firdaus-Nawi, M.; Yusoff, S.M.; Yusof, H.; Abdullah, S.Z.; Zamri-Saad, M. Efficacy of feed-based adjuvant vaccine against Streptococcus agalactiae in Oreochromis spp. in Malaysia. Aquac. Res. 2013, 45, 87-96. [CrossRef]

37. Tafalla, C.; Bøgwald, J.; Dalmo, R.A. Adjuvants and immunostimulants in fish vaccines: Current knowledge and future perspectives. Fish Shellfish. Immunol. 2013, 35, 1740-1750. [CrossRef] [PubMed]

38. Tian, J.; Yu, J.; Sun, X. Chitosan microspheres as candidate plasmid vaccine carrier for oral immunisation of Japanese flounder (Paralichthys olivaceus). Veter- Immunol. Immunopathol. 2008, 126, 220-229. [CrossRef]

39. Plant, P.K.; LaPatra, S.E. Advances in fish vaccine delivery. Dev. Comp. Immunol. 2011, 35, 1256-1262. [CrossRef]

40. Siripornadulsil, S.; Dabrowski, K.; Sayre, R. Microalgal vaccines. Transgenic microalgae as green cell factories. In Transgenic Microalgae as Green Cell Factories; Springer: Berlin/Heidelberg, Germany, 2007; pp. 122-128.

41. Patel, P.; Patel, B.; Amaresan, N.; Joshi, B.; Shah, R.; Krishnamurthy, R. Isolation and characterization of Lactococcus garvieae from the fish gut for in vitro fermentation with carbohydrates from agro-industrial waste. Biotechnol. Rep. 2020, 28, e00555. [CrossRef]

42. Ranjan, R.; Prasad, K.P.; Vani, T.; Kumar, R. Effect of dietary chitosan on haematology, innate immunity and disease resistance of Asian seabass Lates calcarifer (Bloch). Aquac. Res. 2014, 45, 983-993. [CrossRef]

43. Zhang, J.; Kong, X.; Zhou, C.; Li, L.; Nie, G.; Li, X.J.F. Toll-like receptor recognition of bacteria in fish: Ligand specificity and signal pathways. Fish Shellfish. Immunol. 2014, 41, 380-388. [CrossRef] [PubMed]

44. Fan, J.Z.; Jia, Q.J.; Yao, C.L. Characterization and expression analysis of Toll-like receptor 2 gene in large yellow croaker, Larimichthys crocea. Fish Shellfish. Immunol. 2015, 44, 129-137. [CrossRef]

45. Yin, Z.; Kwang, J. Carp interleukin-1 $\beta$ in the role of an immuno-adjuvant. Fish Shellfish. Immunol. 2000, 10, 375-378. [CrossRef] [PubMed]

46. Clay, H.; Volkman, H.E.; Ramakrishnan, L. Tumor necrosis factor signaling mediates resistance to mycobacteria by inhibiting bacterial growth and macrophage death. Immunity 2008, 29, 283-294. [CrossRef] [PubMed]

47. Rao, S.; Byadgi, O.; Pulpipat, T.; Wang, P.C.; Chen, S.C. Efficacy of a formalin-inactivated Lactococcus garvieae vaccine in farmed grey mullet Mugil cephalus. J. Fish Dis. 2020, 43, 1579-1589. [CrossRef] [PubMed]

48. Mutoloki, S.; Munang'andu, H.M.; Evensen, Ø. Oral Vaccination of Fish-Antigen Preparations, Uptake, and Immune Induction. Front. Immunol. 2015, 6, 519. [CrossRef] [PubMed]

49. Mao, Z.; Ye, J.; Li, M.; Xu, H.; Chen, J. Vaccination efficiency of surface antigens and killed whole cell of Pseudomonas putida in large yellow croaker (Pseudosciaena crocea). Fish Shellfish. Immunol. 2013, 35, 375-381. [CrossRef]

50. Siriyappagouder, P.; Shankar, K.M.; Naveen Kumar, B.T.; Patil, R.; Byadgi, O.V. Evaluation of biofilm of Aeromonas hydrophila for oral vaccination of Channa striatus. Fish Shellfish. Immunol. 2014, 41, 581-585. [CrossRef] [PubMed]

51. Halimi, M.; Alishahi, M.; Abbaspour, M.R.; Ghorbanpoor, M.; Tabandeh, M.R. Valuable method for production of oral vaccine by using alginate and chitosan against Lactococcus garvieae/Streptococcus iniae in rainbow trout (Oncorhynchus mykiss). Fish Shellfish. Immunol. 2019, 90, 431-439. [CrossRef] [PubMed] 